\title{
Serum uric acid levels in normal pregnancy with observations on the renal excretion of urate in pregnancy
}

\author{
JAMES A. BOYLE, STUART CAMPBELL, ANNE M. DUNCAN, \\ WILLIAM R. GREIG, AND W. WATSON BUCHANAN \\ From the Centre for Rheumatic Diseases, Glasgow, the University Department of Obstetrics, \\ Queen Mother's Hospital, Glasgow, and the Department of Biochemistry, Royal Infirmary, \\ Glasgow
}

SYNOPSIS Serum uric acid estimations were performed in 106 healthy pregnant women during early, middle, and late pregnancy, using an automated colorimetric method. The mean serum uric acid level was significantly lower during early and middle pregnancy than that of 64 age-matched female controls. The serum uric acid level was not significantly different in late pregnancy from the control group. Studies of the daily urinary urate excretion in 31 pregnant women showed normal urinary urate excretion in early pregnancy and enhanced renal loss of urate in middle and late pregnancy. It appears that the renal clearance of urate in pregnancy is high, especially in the middle period when the serum level is low in spite of the increased production of uric acid by the foetus.

Pregnancy has a favourable influence on the symptoms of gout (Lee and Loeffler, 1962), and, although gout is uncommon in premenopausal women, exacerbations have occurred in the puerperium (Greenhut, Silver, and Campbell, 1953). Weingold (1960) reported a patient with gout who remained symptom-free during her pregnancy but had an acute attack of gout 18 hours after delivery.

These observations prompted interest in the influence of pregnancy on the serum uric acid level. The vast majority of the very numerous studies of serum uric acid levels in pregnant women have been concerned with the rise which occurs in preeclampsia. Only one study to our knowledge deals with the serum uric acid level in normal pregnancy (Steenstrup, 1963) where low values were encountered. We felt that it would be of value to confirm this work and to investigate the cause of the hypo-uricaemia.

\section{MATERIALS AND METHODS}

One hundred and six pregnant women were studied. The mean age was 25.8 years (range 17 to 49 years). Forty-four patients were in early pregnancy ( 0 to 16 weeks), 48 were in middle pregnancy (17 to 28 weeks), and 14 were in late pregnancy (over 28 weeks). These women were all

Received for publication 7 February 1966. attending an antenatal clinic. No patients in this study had essential hypertension, chronic nephritis or preeclampsia; none were receiving salicylates at the time of study, none had a raised blood pressure $(140 / 90 \mathrm{~mm}$. of mercury or more) or demonstrated albuminuria. Mild ankle oedema was not taken as a contraindication to inclusion in the study unless it was associated with signs of pre-eclampsia. All patients studied were healthy in other respects.

The control sample consisted of 64 healthy nonpregnant women who had been seen in the course of a twin study and who had been drawn from the general population by advertisement in the press The mean age of the sample was 19.3 years and the range 12 to 40 years.

Venous blood was taken into a glass container and allowed to clot. Serum samples from all subjects were frozen and stored for at least three weeks before determination of the uric acid concentration, because Buchanan, Isdale, and Rose (1965) have shown that nonurate chromogens which interfere with the colorimetric methods of uric acid estimation disappear from sera which have been stored frozen for three weeks. Serum uric acid was then measured by the Technicon colorimetric AutoAnalyzer method no. 22.

A further 31 pregnant women satisfying the criteria described above were placed on a diet free from sweetbreads, liver, heart, kidney, and brain for three days and a 24-hour urine sample was collected on the third day. Ten of these patients were in early pregnancy, nine were in middle pregnancy, and 12 were in late pregnancy. Thirteen healthy non-pregnant women, members of the 


\section{James A. Boyle, Stuart Campbell, Anne M. Duncan, William R. Greig, and W. Watson Buchanan}

nursing staff, on a similar diet for three days, provided 24-hour urine samples. The urine specimens also were frozen and stored for at least three weeks. Urine uric acid concentration was measured by taking $5 \mathrm{ml}$. aliquots of urine, diluting to 1 in 10 with distilled water, and measuring uric acid in $0.5 \mathrm{ml}$. of the diluted sample. The 24-hour urinary uric acid excretion was then calculated.

\section{RESULTS}

The results are shown in Tables I and II. The mean serum uric acid in the control group was $3.86 \mathrm{mg}$./ $100 \mathrm{ml}$. with a standard deviation of $0.72 \mathrm{mg} . / 100 \mathrm{ml}$. In early pregnancy the mean serum uric acid was significantly lower, being $2.72 \pm 0.62 \mathrm{mg} . / 100 \mathrm{ml}$. $(\mathbf{P}<0.001)$. The uric acid concentration was also low in the group of women studied in middle pregnancy $(2.60 \pm 0.54 \mathrm{mg} . / 100 \mathrm{ml} ., \mathrm{P}<0.001)$ but in late pregnancy the mean value was $3.61 \pm 0.75 \mathrm{mg}$./ $100 \mathrm{ml}$., a value which is not significantly different from the non-pregnant mean concentration.

\section{TABLE I}

SERUM URIC ACID LEVELS IN A GROUP OF NON-PREGNANT WOMEN CONTRASTED WITH THE VALUES FOUND IN GROUPS IN EARLY, MIDDLE, AND LATE PREGNANCY

\begin{tabular}{lcccc} 
& $\begin{array}{l}\text { Non- } \\
\text { pregnant }\end{array}$ & $\begin{array}{l}\text { Early } \\
\text { Pregnancy }\end{array}$ & $\begin{array}{l}\text { Middle } \\
\text { Pregnancy }\end{array}$ & $\begin{array}{l}\text { Late } \\
\text { Pregnancy }\end{array}$ \\
\hline Mean & & & & \\
Standard deviation & 0.86 & 2.72 & 2.60 & 3.61 \\
Number studied & 64 & 0.62 & 0.54 & $0 \cdot 75$ \\
& 64 & 44 & 48 & 14
\end{tabular}

${ }^{1}$ Mean for non-pregnant $v$. mean for early pregnancy. $t=8.8$; $\mathbf{P}<0.001$.

Mean for non-pregnant $v$. mean for middle pregnancy. $t=10 \cdot 5$; $\mathbf{P}<0.001$.

\section{TABLE II}

TWENTY-FOUR HOUR URINARY URATE EXCRETION VALUES FOR A GROUP OF NON-PREGNANT WOMEN CONTRASTED WITH THE VALUES FOUND IN GROUPS IN EARLY, MIDDLE, AND LATE PREGNANCY

Non- Early Middle Late pregnant Pregnancy Pregnancy Pregnancy

\begin{tabular}{lrrrr}
\hline Mean $^{1}$ & 601 & 608 & 926 & 832 \\
Standard deviation & 130 & 174 & 166 & 137 \\
Number studied & 13 & 10 & 9 & 12
\end{tabular}

$\begin{array}{lllll}\text { Number studied } & 13 & 10 & 9 & 12\end{array}$

${ }^{1}$ Mean for non-pregnant $v$. mean for middle pregnancy. $t=4.93$; $P<0.001$.

Mean for non-pregnant $v$. mean for late pregnancy. $t=4 \cdot 36$; $P<0.001$.

Table II shows the value for the 24-hour urinary urate excretion. The control group excreted a mean value of $601 \mathrm{mg}$. per day, the standard deviation being $130 \mathrm{mg}$. In early pregnancy the mean urate excretion per day was $608 \pm 174 \mathrm{mg}$. A high daily excretion was observed in the groups studied in middle and late pregnancy, the values being $926 \pm$ $166 \mathrm{mg}$. and $832 \pm 137 \mathrm{mg}$. respectively; these two values are significantly higher than those of both the control group and the patients studied in early pregnancy $(\mathrm{P}<0.001)$.

\section{DISCUSSION}

These results show that the blood uric acid level falls in early and in middle pregnancy and rises to normal values in late pregnancy. We have also demonstrated in the present study a normal daily urinary urate excretion in early pregnancy and an enhanced renal loss of urate in middle and late pregnancy. Steenstrup (1963) reports an increased renal clearance of urate in early and middle pregnancy but does not comment on the urate excretion in late pregnancy.

Pregnancy is a most complex physiological situation and interpretation of our results is therefore difficult. Although we have found increased renal excretion of urate in pregnancy it is unlikely that this is the sole factor responsible for the changes which have been observed in the serum uric acid concentration for the following two reasons.

First, in early pregnancy the serum uric acid is low while there is no change in the renal excretion of urate. Secondly, when the serum uric acid concentration is normal in late pregnancy, a high renal loss of urate obtains. It is unlikely that diminished uric acid production is responsible for the hypouricaemia because Steenstrup (1963) has demonstrated normal uric acid production in early pregnancy.

Our findings may have the following explanation: initially early hypervolaemia of pregnancy, such as has been shown to exist by Hytten and Paintin (1963) as early as 12 weeks, may produce a dilution hypouricaemia; the finding of a normal 24-hour urinary urate excretion in the presence of a low serum uric acid concentration indicates that the renal clearance of uric acid must be raised at this time. Increased uric acid clearance will then be responsible for the low uric acid levels found. In middle pregnancy the serum uric acid level is even lower but the 24-hour urinary urate excretion is above normal. These facts suggest a further increase in uric acid clearance by the kidneys in this stage of pregnancy. It is also probable that in middle pregnancy significant transfer of uric acid from the growing foetus to the maternal blood stream is beginning to occur. In late pregnancy the normal serum uric acid levels possibly indicate that the high renal uric acid clearance is not sufficient to clear from the mother's blood the increasing amounts of uric acid produced by the foetus.

It is clear that further studies of uric acid production and excretion in mother and foetus are called 
for, particularly in an attempt to define the mechanism of increased renal clearance of uric acid which occurs in normal pregnancy.

\section{REFERENCES}

Buchanan, M. J., Isdale, I. C., and Rose, B. S. (1965). Ann. rheum. Dis., 24, 285.
Greenhut, I. J., Silver, R. A., and Campbell, J. A. (1953). Radiology, 60, 257.

Hytten, F. E., and Paintin, D. B. (1963). J. Obstet. Gynaec. Brit. Cwlth, 70, 402.

Lee, F. I., and Loeffler, F. E. (1962). Ibid., 69, 299.

Steenstrup, O. R. (1963). Urinsyrestudier pa normale gravide. Universitetsforlaget, Aarhus.

Werngold, A. B. (1960). Obstet. and Gynec., 16, 309.

\section{Broadsheets prepared by the Association of Clinical Pathologists}

The following broadsheets (new series) are published by the Association of Clinical Pathologists. They may be obtained from Dr. R. B. H. Tierney, Pathological Laboratory, Boutport Street, Barnstaple, N. Devon. The prices include postage, but airmail will be charged extra.

13 The Identification of Serotypes of Escherichia coli Associated with Infantile Gastro-enteritis. 1956. JOAN TAYLOR. $1 \mathrm{~s}$.

16 Preservation of Pathological Museum Specimens. 1957. L. W. PROGER. 1s.

17 Cultural Diagnosis of Whooping-cough. 1957. B. W. LACEY. $1 \mathrm{~s}$.

20 Investigation of Porphyrin/Porphyria. 1958 (reprinted 1962). C. RIMINGTON. 2s.

23 The Dried Disc Technique for Bacterial Sensitivity Tests. 1959. R. W. FAIRBROTHER and J. C. SHERRIS. 1s.

24 Safe Handling of Radioactive Tissues in the Laboratory and Post-mortem Room. 1959. R. C. CURRAN. 1s.

26 The Periodic Acid-Schiff Reaction. 1959. A. G. E. PEARSE. 1s.

28 Daily Fatty Acid Excretion. 1960. A. C. FRAZER. 2s.

29 The Preparation of Bone for Diagnostic Histology. 1960. D. H. COLLINS. 2s.

30 Control of Accuracy in Chemical Pathology. 1961. G. H. GRANT. 4s.

31 Investigation of Haemorrhagic States with Special Reference to Defects of Coagulation of the Blood. 1961. E. K. BLACKBURN. 4s.

32 Detection of Resistance to Streptomycin, P.A.S., and Isoniazid in Tubercle Bacilli. 1961. R. CRUICKSHANK and S. M. STEWART. $2 \mathrm{~s}$.

33 The Laboratory Detection of Abnormal Haemoglobins. 1916 (reprinted 1965). H. LEHMANN and J. A. M. AGER. $4 \mathrm{~s}$.

34 Titration of Antistreptolysin O. 1961. H. GOODER and R. E. O. WILliams. 2s.

35 The Estimation of Faecal 'Urobilinogen'. 1961. C. H. GRAY. 2 s.

36 Quantitative Determination of Porphobilinogen and Porphyrins in Urine and Faeces. 1961. C. RIMINGTON. 3s. 6d.
37 The Paper Electrophoresis of Serum and Urinary Proteins. 1961. G. FRANGLEN and N. H. MARTIN. 4s.

38 The Augmented Histamine Gastric Function Test. 1961. M. LUBRAN. 2s.

39 Investigation of Haemolytic Anaemia. 1961. J. G. SELWYN. 2s.

40 Short-term Preservation of Bacterial Cultures. 1962. E. JOAN STOKES. 2s.

41 Serological Tests for Syphilis. 1962. A. E. WILKINSON. 6s.

42 The Determination of Glucose 6-Phosphate Dehydrogenase in Red Cells. 1962 . T. A. J. PRANKERD. $2 s$.

43 Mycological Techniques. 1962 (reprinted 1966). R. W. RIDDELL. 3s. 6d.

44 The Laboratory Investigation of Catecholamine Secreting Tumours. 1963. M. SANDLER and C. R. J. RUTHVEN. $2 s$.

45 Diagnostic Test for Hereditary Galactosaemia. 1963. v. SCHWARTZ. 2 s.

46 The Determination of Serum Iron and Total Iron Binding Capacity. 1963. A. JORDAN and D. A. PODMORE. 2s.

47 Nuclear Sexing. 1964. B. LENNox and $\mathbf{W}$. DAVIDSON. 2s.

48 The Laboratory Investigation and Control of the Defibrination Syndrome. 1964. R. M. HARDISTY, G. I. C. INGRAM, and A. A. SHARP. 3s. 6d.

49 Rapid Diagnostic Section Technique. 1965. N. J. BROWN and A. T. SANDISON. 2 s.

50 The Collection, Preservation and Staining of Specimens for Gynæcological Cytology. 1965. ERICA WACHTEL. 4s.

51 Histological Fixation of Human Tissues. 1966. A. C. LENDRUM. $2 \mathrm{~s}$.

52 Simple Tests to Detect Poisoning. 1966. A. S. CURRY. 4s.

53 Preparation of Sections from Bone Marrow Biopsies. 1966. A. G. SIGNY and D. ROBERTSON SMITH. 2 s. 